\title{
A Comparative Analysis of Educational Donors in the Netherlands
}

Received (in revised form): March 24, 2008

\section{Russell N. James III}

J.D., Ph.D. is an assistant professor at the University of Georgia at the Institute for Nonprofit Organizations and the Department of Housing and Consumer Economics. Previously, Dr. James served for six years as the director of planned giving and for six years as college president at Central Christian College in Moberly, Missouri.

\section{Pamala Wiepking}

is a faculty member in the Department of Philanthropic Studies at the VU University Amsterdam, The Netherlands. Her research focuses on charitable giving.

\begin{abstract}
Using data from 1,373 households participating in the 2005 Giving in the Netherlands Panel Survey, this paper examines the characteristics of educational donors in comparison with other types of charitable donors and with nondonors. Charitable giving is quite common in the Netherlands, but there is no established higher education advancement profession. Similar to US findings, Dutch educational donors were among the most generous, giving more than other donors did to religion and other noneducational charities. Educational gifts were, however, much smaller in the Netherlands. Probit and
\end{abstract}

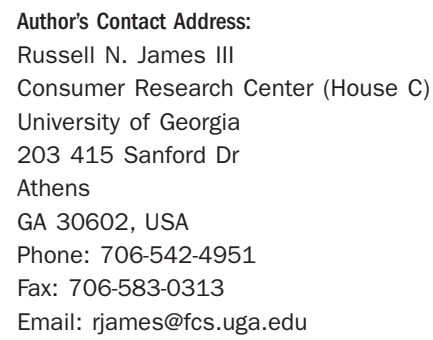

Tobit analyses revealed the dominant importance of the presence of children in the home in predicting educational charitable giving. Dutch educational giving may be more focused on small gifts supporting extra-curricular primary school activities, rather than large gifts to higher education. The absence of a strong positive effect of graduate education, such as was found in previous US research on educational giving, may result from a difference in philanthropic cultures regarding higher education. International Journal of Educational Advancement (2008) 8, 71-78. doi:10.1057/ijea.2008.9

Keywords:

Netherlands fundraising, donor characteristics, philanthropic culture

\section{Introduction}

This study examines the characteristics associated with making charitable gifts to educational institutions, using data 
from the Netherlands. In a previous study on the characteristics of educational donors in the US, James (2008) found several factors significant in predicting educational giving, including income, wealth, age, the presence of children in the home, and marital status. Extending this examination to the Netherlands serves several important purposes. First, the attempted replication of these findings in a multi-national context may provide insight into which, if any, characteristics are consistent predictors of charitable giving to education across cultures. Secondly, a comparable examination using Dutch data is particularly interesting because of the Netherlands' combination of relatively high percentages of charitable giving participation with the lack of an established higher education advancement profession. Further, the Netherlands has only one private university, as compared with 14 public universities.

According to results from the 2002/2003 European Social Survey, the proportion of Dutch households making charitable gifts is higher than any other European nation (Adloff, 2007). Using the detailed and lengthy survey methodology best suited to reveal the most information about charitable giving suggests that no less than 95 percent of all Dutch households contribute to charity each year (Wiepking, 2007).

Against this background of a positive charitable giving climate, the Netherlands has a relatively less developed tradition of fundraising in higher education than the US. There is only one private university in the Netherlands. Although a few of the 15 Dutch universities have alumni offices, in most cases these do not include any full-time employees focused on fundraising. The common examples of buildings, schools, and endowed professorships named for private donors found in US universities are largely absent in the Netherlands.

There is, however, a growing phenomenon of donations to primary schools. These gifts are used to enhance the regular academic programs with field trips, renovations to playgrounds, and the like. Similar to American parent-teacher organizations, local Dutch voluntary parents' councils will often identify needed projects and raise funds for their completion (Dutch Department of Education, 2005).

The relatively higher taxation rates in the Netherlands provide funds that, among many other things, support all Dutch universities. This expectation of government support may work against the development of charitable giving in higher education. Such effects would be consistent with a variety of studies suggesting that government support can crowd out private support, at least to some extent (Eckel et al., 2005; Kingma, 1989; Payne, 1998). Further, such government support may also work against the development of a higher education fundraising profession by crowding out fundraising activities (Andreoni and Payne, 2003).

\section{Data}

Data for this analysis came from the 2005 Giving in the Netherlands Panel Study (GINPS). The main objective of the GINPS was to map household contributions to the philanthropic sector in the Netherlands. Data were collected by the Dutch Institute for Public Opinion and Market Research. 
The GINPS questioned respondents immediately after their tax return due date, perhaps aiding in the recall process for those deducting such contributions on their tax returns. Questions were asked about any donating behavior of household members in the preceding calendar year. Respondents were drawn from a pool of 72,000 participants who regularly took part in marketing and opinion research conducted by the Dutch Institute for Public Opinion and Market Research data. (This could cause some selection bias, as regular responders may be more likely to exhibit other pro-social activities such as charitable giving.) A sample of 1,868 individuals was contacted from this larger pool and 1,474 (79 percent) responded to the request by completing the survey. This original sample included an intentional oversampling of Protestants. This oversample $(n=101)$ was removed from the final analysis to make the resulting sample more nationally representative.

Measuring the total number of households making charitable gifts can present a challenge, as results vary widely depending upon the survey methodology employed (Bekkers and Wiepking, 2006). In this study, information on charitable giving came from responses to a long series of questions intended to elicit the most complete reporting of charitable activity. Respondents were first asked whether anyone in their household gave funds using any of 28 different possible methods of giving (e.g., doorto-door collections, direct mail appeals, etc.). After these questions, respondents were also asked whether or not their household made a donation to any of ten different kinds of charitable causes: religion, health, international aid, environment/nature protection, animal protection, education/research, culture, sports/ recreation, public/social benefits, and other causes. Where donations were indicated, the exact amount of money given in the year 2005 was requested. In order to minimize respondents' tendency to give socially desirable rather than accurate answers, the data were collected using a Computer Assisted Self-Administered Interview procedure with no interpersonal interaction during the response process.

\section{Descriptive Analysis}

Table 1 reports group means for those who donated to education (educational donors), those who donated, but not to education (noneducational donors), and those who made no donations (nondonating). Overall, 7.6 percent of all Dutch households made gifts to education. This compares with 6.7 percent of all US households making educational gifts in the 1995-2005 Consumer Expenditure Surveys (James, 2008). This difference may, however, be driven in part by variation in survey methodology, as the US data are based upon four summary questions regarding the type of charitable recipient, rather than the detailed prompting found in the GINPS (Bekkers and Wiepking, 2006). Among educational donors, the annual average of household gifts to education in the GINPS was 48.70 Euros (or 60.54 dollars, based upon the average daily exchange rates in 2005). In contrast, the average household gift to education among educational donors reported in the 1995-2005 US Consumer Expenditure Surveys was 
Table 1: Descriptive statistics giving in the Netherlands panel study 2005, weighted $N=1,374$ (standard error)

\begin{tabular}{|c|c|c|c|}
\hline & $\begin{array}{l}\text { All Nondonating } \\
\text { households }\end{array}$ & Noneducational donors & Educational donors \\
\hline$N$ & 82 & 1,188 & 104 \\
\hline Annual after-tax income & $22,780.53(14,857.41)$ & $25,050.33(14,640.50)$ & $27,451.47(21,246.54)$ \\
\hline Income from wealth $(\%)$ & 4.6 & 8.9 & $16.2 *$ \\
\hline All charitable giving & - & $229.57(13.44)$ & $516.28(74.63)^{*}$ \\
\hline Religious giving & - & $94.61(8.79)$ & $232.37(49.93)^{*}$ \\
\hline Relief giving & - & $43.96(2.97)$ & $67.06(19.29)^{* *}$ \\
\hline Miscellaneous giving & - & $91.01(6.15)$ & $168.14(29.28) *$ \\
\hline Age & 42.4 & 45.6 & 44.8 \\
\hline Family size & $2.77(1.41)$ & $2.65(1.33)$ & $3.2(1.65)^{*}$ \\
\hline Married (\%) & 46.9 & 57.7 & 59.5 \\
\hline Single male $(\%)$ & 24.0 & 12.6 & 8.2 \\
\hline Single female $(\%)$ & 4.9 & 13.6 & 11.6 \\
\hline$<$ High school $(\%)$ & 30.6 & 23.1 & $12.4 *$ \\
\hline HS graduate $(\%)$ & 49.2 & 48.8 & 52.9 \\
\hline Bachelor's degree $(\%)$ & 15.6 & 19.9 & 24.8 \\
\hline Graduate degree $(\%)$ & 4.7 & 8.3 & 10.0 \\
\hline Urban $(\%)$ & 90.5 & 85.4 & 88.8 \\
\hline Respondent over $64(\%)$ & 12.9 & 16.4 & 14.7 \\
\hline Children living at home (\%) & 47.1 & 45.0 & $61.7^{*}$ \\
\hline Homeowner $(\%)$ & 50.5 & 64.0 & 69.7 \\
\hline Renter $(\%)$ & 49.5 & 36.0 & 30.0 \\
\hline
\end{tabular}

*Indicates difference significant at $p<0.01$ (one-sided $t$-test for equality of means, equal variances assumed); **indicates that difference from noneducational donors is significant at $p<0.05$.

Source: GINPS, amount donated in Euros, weighted means, Protestant over sample (N=101) excluded.

The actual number of cases is 1,367 (78 nondonors, 1,186 noneducational donors, 103 educational donors), weighting increases this to 1,374 .

Mean amounts donated based on multiple imputed data for missing amounts; reported descriptive results from first imputation (amounts donated not weighted).

$\$ 543.14$, measured in inflationadjusted 2005 dollars (James, 2008). Similarly, 18.4 percent of all charitable giving by educational donors in the US survey was directed toward education, as compared with 9.4 percent of all charitable giving by educational donors in the Netherlands.

While 7.6 percent of Dutch households did make gifts to education, these gifts were much smaller than educational gifts in the US, both in absolute terms and as a percentage of total charitable gifting. These results may suggest that Dutch educational giving could be more heavily skewed towards small gifts that support primary school extra-curricular programming, especially in households with minor children attending such schools. Further supporting this possibility is the dramatic difference in the presence of minor children in educational donor households. Overall, only 38.8 percent of US educational donor households had minor children living at home as compared with 61.7 percent of Dutch educational donor households. The difference in the presence of children between 
educational donor households and other donor households was also greater in the Netherlands. Nearly 62 percent of all Dutch educational donor households had children living in the home, compared with only 45 percent of donor households that did not give to education. This nearly 17 percent difference compares with only a 3.8 percent difference seen in the US data when comparing educational donor households with other donor households.

While these characteristics are consistent with a possible difference in the type of educational recipient, neither survey provides direct evidence on this issue. The definition of educational giving in both the GINPS and the US Consumer Expenditure Survey did not specify whether educational giving was directed towards primary, secondary, or postsecondary education. The survey instrument for the US Consumer Expenditure Survey included the examples of "alumni funds, scholarship funds, educational endowments, and school fund-raisers" (US Census Bureau, 2004, p. 60).

Along with these cross-national differences, some similarities emerged in the US and Dutch surveys. In both cases, educational donors were broadly generous, giving significantly more to religious and miscellaneous organizations than noneducational donors. Educational donors were wealthier than other types of donors in both countries. Also, educational donors were less likely to have very low levels of education than noneducational donors in both countries. The dramatic concentration of those with graduate degrees found in the US data was, however, not as pronounced in the Dutch survey. While the US data indicated that 30.7 percent of educational donors had graduate education as compared with 9.9 percent of noneducational donors, the Dutch results showed a statistically insignificant difference of 10 percent graduate degrees for educational donors and 8.3 percent for noneducational donors.

One possible explanation for the difference is the US graduate student's likely receipt of benefits from previous donors to higher education. This may lead to an increased likelihood of "reciprocal" giving following graduation. In the absence of a tradition of developing and recognizing the importance of private donations to higher education, the Dutch graduate education experience may naturally produce dissimilar results in future educational giving.

\section{Regression Models}

We present regression models measuring both the likelihood of making charitable gifts to education and the expected value of gifts to education. These regression models allow for an examination of the association of educational giving with a particular variable while holding the value of all other variables constant.

\section{Probit analysis}

The Probit analysis models the association of various factors with the presence of an educational charitable gift. In this model the outcome is either 1 if the household made a charitable gift to education in the previous year or 0 if it did not. Thus, there is no distinction between making a small, medium, or large gift for this model. 
Table 2: Regressions on likelihood and amount of educational gifting, reporting multiple imputation parameter estimates using nine imputations and (standard errors)

\begin{tabular}{lcc}
\hline & $\begin{array}{c}\text { Probit on presence of } \\
\text { educational giving }\end{array}$ & $\begin{array}{c}\text { Tobit on level of } \\
\text { educational giving }\end{array}$ \\
\hline Income (€ 10,000 units) & $0.0137(0.0333)$ & $-4.7473(12.5850)$ \\
Wealth & $0.2803(0.1619)$ & $78.3660(45.2134)$ \\
Homeowner & $0.0026(0.1188)$ & $14.0035(33.5403)$ \\
Age & $0.0042(0.0040)$ & $0.8060(1.1370)$ \\
Children living at home & $0.4301(0.1265)^{* *}$ & $97.2760(36.0406)^{*}$ \\
Single male & $-0.0974(0.1847)$ & $-48.7518(55.4268)$ \\
Single female & $0.0489(0.1699)$ & $-9.1125(52.5137)$ \\
Urban & $0.1825(0.1604)$ & $45.8695(44.5133)$ \\
HS graduate & $0.2776(0.1542)$ & $63.2747(45.9575)$ \\
Bachelor's degree & $0.4532(0.1806) * *$ & $134.5552(54.4340)^{* *}$ \\
Graduate degree & $0.4266(0.2390)$ & $128.2381(68.7560)$ \\
Intercept & $-2.3520(0.3354)^{*}$ & $-605.9970(108.7278)^{*}$ \\
$N$ & 1,367 & 1,367 \\
\hline
\end{tabular}

*Significant at $p<0.01$.

$\because$ Significant at $p<0.05$.

Consistent with the dramatic difference in the presence of minor children found in the descriptive statistics, Table 2 reports that minor children living in the home is the only independent variable associated with the presence of educational giving significant at the 0.01 level. Moving to the 0.05 level of significance, the presence of a college education is also significantly associated with the presence of educational giving. In contrast with the dramatic impact of a graduate education seen in the US results, graduate education in the Netherlands is not a statistically significant indicator of educational giving.

\section{Tobit analysis}

The Tobit analysis measures the predicted level of charitable educational giving. A Tobit analysis is often used in charitable giving analysis, as it is designed to work with data where a substantial portion of the outcome variables are zeros (McDonald and Moffit, 1980). In this case, only 7.6 percent of Dutch households made gifts to educational institutions, meaning that the outcome variable, euros donated to educational institutions, is zero for over 92 percent of the cases. (Thus, an ordinary least squares regression on the amount of educational giving would be an inappropriate methodology for this analysis.) In predicting the level of charitable educational giving, the Tobit analysis considers both the likelihood of making a gift and the level of the gift made. In this way, these results add to the probit analysis, which disregarded the level of gifting.

Despite this difference in methodology, the findings are quite similar. When predicting the level of household educational donations, the presence of children in the home is once again the only variable significant at the 0.01 level. Considering variables 
significant at 0.05 or below results in the inclusion of the respondent having a bachelor's degree as being significantly associated with higher levels of educational giving. No other independent variables are statistically significant, including, once again, the dominant factor from the US analysis-the presence of graduate education.

\section{Summary}

While charitable giving is quite prevalent in the Netherlands, giving to higher education is much less developed. Although both US and Dutch surveys combined all forms of educational giving, several factors suggest that Dutch educational giving may be directed more at making small gifts to primary schools for extracurricular activities, rather than making larger gifts to universities. Throughout all analyses, the dominant factor associated with educational giving in the Netherlands was the presence of children in the home. This association was relatively stronger for Dutch educational giving as compared with previous research on US educational giving.

Previous findings from US data indicated the dominant importance of a graduate education in predicting educational giving. This finding led to the suggestion that "education tends to replicate itself through educational giving" (James, 2008). The present study shows that this central finding of the US analysis is not universal. The Netherlands provides an especially instructive comparison because of the absence of an established higher education advancement tradition.

Economic theory suggests that the higher levels of government support of higher education in the Netherlands may have had a negative effect on the development of this tradition. Most commonly, this concept of "crowding out" private donations through government support is analyzed in terms of its effect on donor behavior (Eckel et al., 2005; Kingma, 1989; Payne, 1998). Andreoni and Payne (2003), however, found evidence that government support can also crowd out fundraising activities by charities. The lack of an established fundraising profession among the 15 Dutch universities, and the absence of graduates having received benefits from a previous generation of private donors may be central factors in limiting the development of a culture of giving to higher education.

Those who complete a graduate degree where there has been no recognition of benefit received from private donations may feel little obligation to make donations to higher education in the future. Thus, the making of large gifts to education may not happen automatically through the increase of wealth and educational attainment, even in an especially generous society. Rather, the development of a higher education "reciprocal giving" culture, with an experience of donation benefits, donation requests, and donation expectations, may be a necessary prerequisite to education replicating itself through educational giving.

With the current restructuring of higher education expenditures by the Dutch government, it is essential for Dutch universities to more actively invest in educational advancement programs in order to maintain their budget. These efforts face the daunting 
task of building, from the ground up, a new reciprocal giving culture in Dutch higher education. A first step in this process may be to tackle the difficult task of convincing Dutch graduates, who are educated with strong welfare state principles, that government expenditures on higher education can no longer be the sole source of income for universities that hope to excel in the future.

\section{References}

Adloff, F. (2007), What makes for charitable giving and philanthropy? The case of the childless elderly in Germany and the US, Retrieved March 18, 2008, from European University Institute Website: http://cadmus.iue.it/dspace/ bitstream/1814/7355/1/MWP-2007-20.pdf.

Andreoni, J. and Payne, A.A. (2003), "Do government grants to private charities crowd out giving or fund-raising?," American Economic Review, 93, 3, pp. 792-812.

Bekkers, R. and Wiepking, P. (2006), “To give or not to give, that is the question: How methodology is destiny in Dutch giving data," Nonprofit and Voluntary Sector Quarterly, 35, 3, pp. 533-540.
Dutch Department of Education (MinOCenW) (2005), Voluntary donations by parents: obligatory voluntary (De ouderbijdrage: verplicht vrijwillig), Retrieved March 20, 2008, from the Dutch Department of Education Website: http://www.minocw.nl/documenten/ onderwijs-ouderbijdrage-ouderbijdrage.pdf.

Eckel, C.C., Grossman, P.J. and Johnston, R.M. (2005), "An experimental test of the crowding out hypothesis," Journal of Public Economics, 89, 8, pp. 1543-1560.

James III, R.N. (2008), "Distinctive characteristics of educational donors," International Journal of Educational Advancement, 8, 1, pp. 3-12.

Kingma, B.R. (1989), “An accurate measurement of the crowd-out effect, income effect, and price effect for charitable contributions," Journal of Political Economy, 89, 5, pp. 1197-1207.

McDonald, J.F. and Moffit, R.A. (1980), "The uses of Tobit analysis," The Review of Economics and Statistics, 62, 2, pp. 318-321.

Payne, A.A. (1998), "Does the Government crowdout private donations? New evidence from a sample of non-profit firms," Journal of Public Economics, 69, 3, pp. 323-345.

US Census Bureau (2004), Consumer Expenditure Surveys: Quarterly Interview Surveys: Information Booklet, CE-305, US Department of Labor, Washington, DC.

Wiepking, P. (2007), “The philanthropic poor: In search of explanations for the relative generosity of lower income households," Voluntas, 18, pp. 339-358. 